\title{
APPENDICES
}

\section{Business MEeTing}

The Business Meeting was convened at 4:20 p.m., Thursday, April 10, in the Executive Forum of the ANA Hotel in Washington, D.C. Charles N. Brower, President of the American Society of International Law, presided. After the adoption of the agenda, in memoriam tributes were given for Richard Lillich (by Burns Weston), Michael Cardozo (by Frederick Kirgis), Sam Efron (by Stephen Gibson), James Hyde (by Eric Stein), John McNeill (by Elizabeth Rindskopf), and Joaquin Tacsan (by Edwin Smith).

\section{TRIBUTE TO RICHARD B. LILLICH}

\section{by Burns H. Weston}

Richard Lillich, one of the foremost international law scholars of our times, became a member of the Society in 1955 and played an active role in it until his untimely death in Charlottesville, Virginia on August 3, 1996. Born in Amherst, Ohio on January 22, 1933, he was only sixty-three years old.

Ours is a major loss. In addition to his more than thirty books and vast number of articles and reviews in the fields of international claims, the law of State responsibility, and international human rights, among others, the length and diversity of Professor Lillich's service to the Society was distinguished. He served on its Executive Council for a total of twelve years; he was Rapporteur and then Chair of the Society's Panel on State Responsibility for a total of twenty-three years; and he was leading member of the Board of Editors of the American Journal of International Law for over twenty-six years, responsible for eleven articles, eight reviews, four notes, and eleven other comments. Also noteworthy, he was an advocate of reform who, long before it was politically correct to do so, inspired as Keith Highet has observed, "the significant turnover of rules that loosened the grip of long-term Board members and opened the Board to new faces."

But Professor Lillich's professional contributions went well beyond the Society and superior scholarship. As I wrote in the January issue of the Journal, "he was nothing if he was not the engaged scholar."

In 1965, with a group of international law colleagues from the academy, government, and private practice, he founded the Procedural Aspects of International Law (PAIL) Institute, perhaps best known for its distinguished book series, most of them edited and several of them authored and co-authored by Professor Lillich. In 1958, as a project of the PAlL Institute, he spearheaded the creation of the Washington-based International Human Rights Law Group. Throughout his distinguished career, he actively participated in and significantly influenced the governance and intellectual life of such other key organizations as the International Law Association, The British Institute of International and Comparative Law, and the American Bar Association's Standing Committee on World Order Under Law. In addition, he was, at various times, a legal consultant to the United States Naval War College, the U.S. Department of Justice, the U.S. Department of State, the United States Centre Against Apartheid, and the United Nations Compensation Commission. He also argued before various international tribunals and served as an international legal consultant to numerous law firms and governments.

In all of these engagements, Professor Lillich's credentials were ample and impeccable. A 1954 graduate of Oberlin College, he earned his LL.B. degree from Cornell University in 1957 and his LL.M. and J.S.D. degrees from New York University in 1959 
and 1960. Quickly thereafter, he began his teaching career, first at Indiana University and then at Syracuse University where he was a member of the law faculty and Director of International Legal Studies from 1960 to 1969. In 1968-1969, he held the Charles H. Stockton Chair of International Law at the United States Naval War College, and in 1969 he was appointed to the law faculty of the University of Virginia where, as the Howard W. Smith Professor of Law since 1977, he continued for twenty-seven years until his untimely death last August. Also during these years, he distinguished himself as a Visiting Fellow at Cambridge, Oxford, and the Max Planck Institute in Heidelberg, and at various times he served as a Visiting Professor of Law at New York University, Florida State University, the University of Georgia, and St. Louis University. Beginning in January 1996, he taught, half-time, as the Edward Ball Eminent Professor in International Law at Florida State University.

As is widely known, Professor Lillich and I became serious collaborators, close colleagues, and warm friends, mostly in that order. A very private person, he was not easy to know personally, certainly not quickly. But I do know this: He vigorously sought and displayed energy of mind, body, and spirit in constant and redeeming mix; he was simultaneously a pragmatic realist and zestful idealist; he was analytically and in other ways creative, but also a lover of tradition; he was professionally driven and at the same time ever eager to savor the bounties of life. Perhaps most importantly, he put a high premium on collegial loyalty and other forms of professional friendship, always extending it at least as much as he desired it in return. I and others who knew him are privileged to have had him as our friend. We are all privileged to have had him as our colleague. He will be long remembered and deeply missed.

\section{Tribute To Michael Cardozo}

\section{by Frederic L. Kirgis}

Mike Cardozo died of chronic lung disease on October 20, 1996, at the age of eighty-six. He was a leader in legal education and in the American Society of International Law.

After private practice in New York City and stints of government service, including seven years in the Legal Adviser's Office at the State Department, he taught at the Cornell Law School for eleven years, mostly teaching International Law and Conflict of Laws. Then he left to become the first Executive Director of the Association of American Law Schools in Washington. During his time with the AALS, there were many firsts: AALS sections were established; the Faculty Recruitment Conference was begun; Supreme Court Previews were first published; and Law Teaching Clinics were first offered.

He was a member of the ASIL for almost fifty years. From 1978 to 1994 he served as Secretary of the Society. At the time of his death he was an Honorary Vice President. Over the years he served on many Society committees, and was a force especially on the Budget Committee from 1974 to 1990.

Mike had clear and definite opinions and could express them forcefully, yet he wasn't the sort to draw attention to himself. He had a practical rather than theoretical bent, and put it to service for the Society. His sometimes gruff, yet ultimately friendly, presence is missed already in Tillar House. 